Paulina Kruszyńska

Uniwersytet Mikołaja Kopernika w Toruniu

\title{
Rywalizacja w ramach listy wyborczej jako konsekwencja systemu list półotwartych w wyborach do Sejmu RP
}

DOI: $10.19195 / 1643-0328.24 .2$

Słowa kluczowe: system proporcjonalny, głosy preferencyjne, efekt kolejności, lokalność kandydata, tożsamość terytorialna, determinanty indywidualnego sukcesu kandydata

\section{Wprowadzenie}

Niniejszy artykuł traktuje o wyborach do Sejmu Rzeczypospolitej Polskiej. Przyjęte w naszym państwie rozwiązanie systemu proporcjonalnego z listami otwartymi, czy dokładniej - półotwartymi ${ }^{1}$, zakłada, że wyborca ma możliwość oddania swojego głosu nie tylko na określoną listę wyborczą, ale może z tej listy wybrać preferowanego przez siebie kandydata. Mamy więc do czynienia z sytuacją, w której kolejność kandydatów na liście wyborczej jest ustalana przez władze partii politycznych, ale wyborca może tę kolejność „zaburzyć”, czyli wskazać kandydata, który jego zdaniem ma mieć pierwszeństwo w uzyskaniu mandatu.

Trzeba jednak pamiętać, iż polskie rozwiązanie zakłada także, że w procesie transformacji głosów na mandaty w pierwszej kolejności zliczane są wszystkie głosy oddane na listę i według tego wyniku uczestniczy ona w podziale mandatów. Dopiero drugim krokiem jest przydzielanie mandatów poszczególnym kandydatom w kolejności według największej zdobytej przez nich liczby głosów. Jak pisze Jacek Raciborski, kandydat bierze więc udział w skomplikowanej grze. $Z$ jednej strony zależy mu na dobrym wyniku wyborczym wszystkich kandydatów z listy, aby ugrupowanie zdobyło jak najwięcej mandatów. Z drugiej zaś kandydat rywalizuje z pozostałymi osobami z listy, dążąc do maksymalizacji swojego indywidualnego poparcia ${ }^{2}$.

Pomimo tego, że wyborcy wskazują na liście konkretnego kandydata i ich głosy decydują o podziale mandatów, istnieje ogólne przeświadczenie, że to miejsce na liście

\footnotetext{
${ }^{1}$ Charakterystyka poszczególnych typów list została przedstawiona w dalszej części artykułu.

2 J. Raciborski, Rywalizacja czy kooperacja? O listach partyjnych w wyborach parlamentarnych, [w:] Demokracja w Polsce. Doświadczenie zmian, red. U. Jakubowska, K. Skarżyńska, Warszawa 2005, s. 21.
} 
zajmowane przez kandydata jest najważniejszym, a może wręcz jedynym czynnikiem wpływającym na jego sukces wyborczy. Przy każdej elekcji wiele emocji budzi ogłoszenie składu list, ponieważ powszechny jest pogląd o występowaniu efektu kolejności, tzn. prostoliniowej zależności sukcesu wyborczego od wyższego miejsca na liście (niższej liczbie porządkowej). Największe zainteresowanie budzi obsadzenie pierwszych miejsc na liście, ale mówi się także o pojęciu „miejsc mandatowych”, które określa tyle pierwszych pozycji na liście wyborczej, ile w danym okręgu mandatów zdobędzie partia. Komentatorzy życia politycznego zapominają o wadze uprawnień wyborcy lub wręcz ignorują analizy badaczy przedstawiające wyjątki od występowania efektu kolejności.

Niniejszy artykuł wpisuje się w nurt badań nad determinantami zachowań wyborczych elektoratu i podnosi problem rywalizacji kandydatów z tej samej listy wyborczej. Jego celem jest analiza wyników wyborów do Sejmu z 2015 r. pod kątem występowania efektu kolejności oraz interwencyjnego wpływu zastosowania list półotwartych. Autorka stawia także pytanie o znaczenie jednej z determinant indywidualnego sukcesu kandydata - lokalności kandydata. W tym celu prezentuje analizę wyników wyborów z dwóch okręgów wyborczych stanowiących łącznie obszar województwa kujawsko-pomorskiego, z zaznaczeniem, że jest to wstęp do badań w tym przedmiocie na większej próbie.

W pierwszej kolejności omówione zostaną podstawowe cechy systemu proporcjonalnego z listami półotwartymi w wyborach do Sejmu RP. Następne dwie części artykułu dotyczyć będą teoretycznych aspektów i dotychczasowego stanu badań nad efektami kolejności oraz lokalności kandydata. Główny paragraf stanowić będzie prezentacja własnej analizy wyników wyborczych pod kątem wskazanych problemów.

\section{System proporcjonalny z listami półotwartymi w wyborach do Sejmu RP}

Jak wspomniano we wprowadzeniu, polski system wyborczy w wyborach do Sejmu RP jest systemem proporcjonalnym, który różnicuje się pod kątem uprawnień wyborcy $\mathrm{w}$ akcie głosowania. Głosowanie z wykorzystaniem list zamkniętych uprawnia wyborcę do oddania głosu wyłącznie na jedną partię/komitet. Wyborca wybiera zatem opcję polityczną i nie ma możliwości wskazania konkretnego kandydata. Kolejność kandydatów ustalają gremia polityczne i według tej kolejności są przydzielane mandaty. Drugim rozwiązaniem jest głosowanie w ramach list otwartych, w którym wyborca ma możliwość wskazania, kto jego zdaniem ma reprezentować partię/komitet. Lista kandydatów jest ustalona, ale najczęściej jest to kolejność w porządku alfabetycznym. W ramach tego typu można wyróżnić listy półotwarte, $\mathrm{z}$ którymi mamy do czynienia, gdy możliwa do wskazania liczba preferencji jest ograniczona (równa lub większa niż jeden, ale mniejsza niż liczba mandatów możliwych do zdobycia w okręgu). Różnica polega także na sposobie konstruowania listy, ponieważ kolejność jest ustalona przez gremia polityczne w innym niż alfabetyczny porządku. Jakkolwiek wyborcy w dalszym ciągu nie są związani tą propozycją. Ostatnim typem listy jest lista wolna, która wraz z wielokrotnym oddaniem 
głosu uprawnia wyborcę do zestawienia własnej konfiguracji osób pochodzących z różnych partii/komitetów - wyborca ma możliwość „wyjścia” poza jedną listę ${ }^{3}$.

Wybory do Sejmu RP odbywają się z wykorzystaniem list półotwartych, a wyborca wskazuje jedną preferencję - konkretnego kandydata $\mathrm{z}$ wybranej przez siebie opcji politycznej. Głosy są w pierwszej kolejności agregowane w okręgu na poziomie list kandydatów na posłów i na tej podstawie następuje podział mandatów przydzielonych do tego okręgu. Następnie mandaty w ramach partii otrzymują kandydaci według wielkości zdobytego indywidualnego poparcia. Obszar naszego kraju został podzielony na 41 wielomandatowych okręgów wyborczych, w których rozdzielanych jest od 7 do 20 mandatów.

\section{Efekt kolejności}

System proporcjonalny $\mathrm{z}$ listami półotwartymi w teorii oznacza równe szanse wyborcze dla wszystkich kandydatów, bez względu na to, z jakiego miejsca na liście startują w wyborach. Jak się jednak okazuje, kandydaci ulokowani na wyższych miejscach często uzyskują wyższe poparcie. Kamil Marcinkiewicz analizujący wyniki wyborów do Sejmu z 2007 r. uważa, że przyczyną takiego stanu rzeczy może być działanie heurystyk poznawczych ${ }^{4}$. Są to reguły, którymi ludzie kierują się, by formować sądy w szybki i efektywny sposób. Często opierają się one na znacznych uproszczeniach, co powoduje, że mogą prowadzić do błędnych ocen ${ }^{5}$. Zdaniem Marcinkiewicza najprostszą strategią minimalizowania kosztów podjęcia decyzji wyborczej jest opieranie się wyłącznie na informacjach, które znajdują się na karcie wyborczej. W polskich warunkach należą do nich: przynależność partyjna, płeć kandydata (odczytywana na podstawie imienia i nazwiska) oraz miejsce na liście kandydatów. Podczas gdy dwie pierwsze informacje nie mają, zdaniem autora, rzeczywistego wpływu na podjęcie decyzji o wyborze konkretnego kandydata $\mathrm{z}$ listy, wskazuje on na znaczenie miejsca na liście. Uzasadnia to uwarunkowaniami percepcyjnymi wyborców, a mianowicie działaniem efektu pierwszeństwa (dla kandydatów z początku listy) oraz efektu świeżości (dla kandydatów z ostatnich miejsc) ${ }^{6}$.

Podobne spostrzeżenia znaleźć można w rozważaniach Jensa Blom-Hansena, Jørgena Elklita, Sørena Serritzlewa i Louise’a Riis Villadsena, którzy uważają, że efekt kolejności powstaje na skutek działania efektu pierwszeństwa i oznacza gratyfikację wyborczą kandydatów wymienionych (a jednocześnie widzianych) na liście jako pierwszych. Wskazują oni jednak także na drugie możliwe wyjaśnienie, według którego wyborcy mogą utożsamiać zajmowanie wysokiej pozycji na liście wyborczej z wysokimi kwalifikacjami kandydata. Wobec tego precyzyjne zidentyfikowanie występowania bądź nie efektu ko-

${ }^{3}$ A. Sokala, B. Michalak, P. Uziębło, Leksykon prawa wyborczego i referendalnego oraz systemów wyborczych, Warszawa 2013, s. 117-121.

${ }^{4} \mathrm{~K}$. Marcinkiewicz, Electoral contexts that assist voter coordination: Ballot position effects in Poland, „Electoral Studies” 2014, nr 33, s. 333.

${ }^{5}$ E. Aronson, T.D. Wilson, R.M. Akert, Psychologia społeczna, przeł. Joanna Gilewicz, Poznań 2006, s. $148-149$.

${ }^{6}$ K. Marcinkiewicz, op. cit. 
lejności jest trudne ze względu na istnienie poważnego problemu, jakim jest pytanie o to, w jaki sposób odróżnić wpływ miejsca na liście od wpływu indywidualnych cech kandydata lub strategii partii politycznej, które pozwoliły mu uzyskać tę (wysoką) pozycję. Innymi słowy, autorzy podnoszą, że jeśli kolejność kandydatów na liście nie została wyłoniona w sposób losowy, to konieczne jest zwrócenie uwagi na inne czynniki, które mogły wpłynąć na ostateczny wynik wyborczy ${ }^{7}$.

Adam Gendźwiłł i Jacek Raciborski, analizując wyniki wyborów do Sejmu z elekcji od 2001 do 2011 r., zauważyli, że przy badaniu wyłącznie wskaźników koncentracji poparcia na listach wyborczych niezaprzeczalnie widoczne jest działanie efektu kolejności i dominacja sukcesu wyborczego kandydatów umieszczonych na początku list wybor$\mathrm{czych}^{8}$. Autorzy przeprowadzili jednak także symulację wyników wyborów przy zastosowaniu systemu proporcjonalnego z listami zamkniętymi i wykazali, że w 2011 r. około jedna piąta kandydatów uzyskała mandat dzięki głosom preferencyjnym ${ }^{9}$ (kandydaci ci nie uzyskaliby mandatu przy rozdziale mandatów według kolejności miejsc zajmowanych na liście). W 2001 r. było to 122 kandydatów, a w 2005 i $2007-104$ i $88^{10}$. Podobnej symulacji odnośnie do wyborów z lat 2005-2011 dokonał Jarosław Flis, wykazując, że 285 mandatów (a więc 20,7\%, łącznie dla tych trzech elekcji) zostało zdobytych przez kandydatów zajmujących „miejsca niemandatowe”. Autor określa opisaną sytuację mianem „przetasowania"11.

\section{Lokalność jako personal vote-earning atribute}

Uznając, że na sukces wyborczy kandydata wpływa nie tylko kolejność na liście wyborczej oraz iż wyborcy korzystają z dostępnego im głosowania preferencyjnego, należy przeanalizować wewnętrzny wymiar rywalizacji wyborczej ${ }^{12}$. Jeśli kandydat rywalizuje z osobami z tej samej listy wyborczej, musi prowadzić kampanię opartą na indywidualnych

${ }^{7}$ J. Blom-Hansen et al., Ballot position and election results: Evidence from a natural experiment, „Electoral Studies" 2016, nr 44, s. 172.

${ }^{8}$ A. Gendźwiłł, J. Raciborski, Jak głosują wyborcy w warunkach preferencyjnych list wyborczych: przypadek Polski, „Decyzje” 2014, nr 22, s. 60-64.

9 Autorzy wyjaśniają ten termin jako głosy oddane na konkretnego kandydata (A. Gendźwiłł, J. Raciborski, op. cit., s. 50). W dalszej części artykułu pojęcie to będzie używane w tym samym znaczeniu.

${ }^{10}$ Ibidem, s. 64-66.

${ }^{11}$ J. Flis, Złudzenia wyboru. Społeczne wyobrażenia i instytucjonalne ramy w wyborach Sejmu i Senatu, Kraków 2014, s. 212-213, 225-235. Podobną zależność, lecz w mniejszej skali, bo odnośnie do kandydatów tylko jednego ugrupowania - Platformy Obywatelskiej, badał R. Matyja. Wykazał on, że w wyborach z lat 2001-2007 procent kandydatów, którzy uzyskali mandat z „miejsca niemandatowego”, wynosił odpowiednio ok. 27\%, 23\% oraz 20\% (ibidem, Od ruchu „trzech tenorów” do partii Tuska, [w:] Platforma Obywatelska, red. M. Migalski, Toruń 2009, s. 71-73).

12 Szerzej na temat warunków (cech systemu wyborczego), które prowadzą do tego, że kandydaci zabiegają o głosy personalne, oraz o strukturze głosu i konsekwencjach poszczególnych rozwiązań zob. J.M. Carey, M.S. Shugart, Incentives to cultivate a personal vote: A rank ordering of electoral formulas, „Electoral Studies" 1995, nr 4, s. 417-439 oraz M. Jarentowski, Struktura głosu: niepożadane skutki personalizacji, [w:] Niedemokatyczne wymiary demokratycznych wyborów, red. J. Szymanek, Warszawa 2016, s. 32-43. 
cechach, które wyróżnią go spośród innych pretendentów do mandatu i przyczynią się do skupienia głosów na sobie. W literaturze zagraniczenj cechy te określa się mianem personal vote-earning atributes (ang. PVEA) ${ }^{13}$, zaś w polskiej mowa o „determinantach indywidualnego sukcesu kandydata”, wśród których wyróżnia się osobowość (cechy charakteru, temperament), oblicze ideologiczne, kwalifikacje, uprzednie dokonania, osiągnięcia ${ }^{14}$. Atrybutem kandydata może być także lokalność (locality, local ties) rozumiana jako lokalne korzenie, miejsce urodzenia (local roots, local birthplace), aktualne miejsce zamieszkania czy doświadczenie w sprawowaniu władzy na niższym, lokalnym szczeblu (lower-level electoral experience, local-leve political experience $)^{15}$.

Dlaczego jednak lokalność uważana jest za atrybut? Badacze zgodnie twierdzą, że pochodzenie czy życie w danej społeczności, a także wcześniejsza działalność polityczna na rzecz tej społeczności (realizowana z sukcesami i aprobatą) stanowi dla wyborców dowód na to, iż kandydat rozumie potrzeby lokalnej społeczności i będzie je reprezentować na szczeblu ogólnopaństwowym ${ }^{16}$. Problem wpływu lokalności kandydatów na ich wynik wyborczy nie cieszy się jednak dużą popularnością. Michael Jankowski pisze wprost, że czynnik, którym jest lokalność kandydata, jest ignorowany przez większość badaczy zajmujących się PVEA. Autor podnosi, że istnieje stosunkowo niewiele badań na ten temat, a jeszcze mniej dotyczy wyborów przeprowadzanych w systemie proporcjonalnym z listami otwartymi (czy półotwartymi) ${ }^{17}$.

Wśród autorów podejmujących się analiz tego zagadnienia należy wymienić Matthew S. Shugarta i innych, którzy badali wpływ miejsca urodzenia oraz doświadczenia politycznego na szczeblu lokalnym (prior lower-level electoral experience) na podstawie wyników wyborów w Finlandii (elekcja z 1999 r.), Luksemburga (1999), Szwajcarii (1999) - przeprowadzanych $\mathrm{w}$ systemie proporcjonalnym $\mathrm{z}$ listami otwartymi - oraz Norwegii (elekcja z 2001 r.), Portugalii (2000) i Hiszpanii (2000) - przeprowadzanych $\mathrm{w}$ systemie proporcjonalnym $\mathrm{z}$ listami zamkniętymi ${ }^{18}$.

Identyczne czynniki mogące wpływać na indywidualny sukces kandydata uwzględniła w swoich analizach Margit Tavits. Badała ona wybory w Estonii, wykazując ostatecznie, że miejsce urodzenia (local birthplace) nie wpływa na sukces wyborczy kandydata, ale wpływ taki można zauważyć w wypadku posiadania doświadczenia w działalności politycznej na szczeblu lokalnym (local-level political experience) ${ }^{19}$.

${ }^{13}$ M. Jankowski, Voting for locals: Voters's information processing strategies in open-list PR systems, „Electoral Studies" 2016, nr 43, s. 72.

${ }^{14}$ K. Korzeniowski, Psychospołeczne uwarunkowania zachowań wyborczych, [w:] Podstawy psychologii politycznej, red. K. Skarżyńska, Poznań 2002, s. 250-253.

${ }_{15} \mathrm{M}$. Tavits, Effect of local ties on electoral success and parliamentary behavior: the case of Estonia, „Party Politics" 16, 2010, nr 2, s. 215-216.

${ }^{16}$ M.S. Shugart, M.E. Valdini, K. Suominen, Looking for locals: voter information demands and personal vote-earning attributes of legislators under proportional representation, „American Journal of Political Science" 2005, nr 49, s. 438-439.

${ }^{17}$ M. Jankowski, op. cit., s. 73.

18 M.S. Shugart, M.E. Valdini, K. Suominen, op. cit., s. 437-449.

${ }^{19}$ M. Tavits, op. cit., s. 215-235. 
Ostatni czynnik stał się także przedmiotem badań Ger-Jan Puta i Barta Maddensa, którzy testowali znaczenie lokalności kandydatów dla ich wyniku wyborczego na przykładzie proporcjonalnych wyborów z systemem list półotwartych w Belgii. Ponadto zmienną, jaką u estońskiej autorki było lokalne miejsce urodzenia, zamienili oni na lokalne miejsce zamieszkania i postawili pytanie o to, czy istnieje związek między liczbą ludności gminy, w której zamieszkuje kandydat, a liczbą głosów preferencyjnych, które otrzymuje $^{20}$. Tropem tym poszedł w swoich badaniach wspomniany już Michael Jankowski analizujący wpływ lokalności kandydatów na sukces wyborczy w wyborach do senatu Hamburga z 2015 r. Wykazał on, że kandydaci otrzymują więcej głosów w okręgach wyborczych, w których mieszkają, oraz że efekt lokalności jest słabszy, jeśli na liście wyborczej znajduje się więcej kandydatów z tego samego okręgu (można ich nazwać kandydatami o tej samej lokalności). Podobnie jak badacze belgijscy, stwierdził on, że sukces wyborczy kandydata lokalnego jest uzależniony od liczby mieszkańców (a tym samym liczby osób uprawnionych do głosowania) w okręgu, w którym kandydat ten mieszka ${ }^{21}$.

W odniesieniu do polskich wyborów najszersze badania mające za przedmiot wpływ lokalności kandydatów na wynik wyborczy prowadził na podstawie wyników z wyborów z 2007 i 2011 r. Jarosław Flis ${ }^{22}$. Lokalność kandydata zdefiniował on jako pochodzenie $\mathrm{z}$ danego powiatu, odczytywane na podstawie informacji o zameldowaniu, udostępnianych przez Państwową Komisję Wyborczą. Przyjmując takie rozumienie lokalności, autor zauważył, że znacząca większość kandydatów gros zdobytych głosów zawdzięcza swoim rodzimym powiatom. Według niego kandydaci pochodzący z powiatów o większej liczbie mieszkańców i większej liczbie zwolenników danej partii mają większe szanse na osiągnięcie sukcesu wyborczego niż ci pochodzący z mniejszych powiatów lub o mniejszej liczbie zwolenników opcji politycznej ${ }^{23}$. Autor zwraca także uwagę na bardzo ciekawą kwestię dotyczącą strategii budowania list wyborczych przez partie. Jak twierdzi, atrakcyjność kandydatów o lokalnej tożsamości powoduje, że partie starają się budować listy w taki sposób, aby znaleźli się na nich kandydaci ze wszystkich powiatów wchodzących w skład okręgu wyborczego. Lokalni kandydaci mają bowiem zdolność przyciągania nowych wyborców, co sprzyja maksymalizacji poparcia dla całej listy ${ }^{24}$.

\section{Analiza wyników wyborów do Sejmu RP z 2015 r. Efekt kolejności}

W niniejszym paragrafie wyniki wyborów do Sejmu z 2015 r. zostaną poddane analizie w celu zidentyfikowania występowania efektu kolejności, interwencyjnego wpływu gło-

${ }^{20}$ G. Put, B. Maddens, The effect of local ties on the electoral success of Belgian/Flemish party candidates: a multilevel analysis, Belgian-Dutch Political Science Conference, Ghent, Belgia, 30-31.05.2013.

${ }^{21}$ M. Jankowski, op. cit., s. 72-84.

22 J. Flis, Głos preferencyjny - złudzenie wyboru, [w:] Oblicza polskiego systemu politycznego, red. B. Krauz-Mozer, K. Sobolewska-Myślik, Toruń 2007; idem, Złudzenia..., s. 201-408.

${ }^{23}$ J. Flis, Złudzenia...., s. 341-342.

${ }^{24}$ Ibidem, s. 338-340. 
sowania preferencyjnego na zdobycie mandatu oraz wpływu lokalności kandydata na jego sukces wyborczy.

W analizowanej elekcji w podziale mandatów uczestniczyło 5 komitetów wyborczych: Prawo i Sprawiedliwość (235 mandatów), Platforma Obywatelska (138), „Kukiz'15” (42), Nowoczesna Ryszarda Petru (28) oraz Polskie Stronnictwo Ludowe (16). Tabela 1 przedstawia wyniki ugrupowań pod kątem liczby mandatów zdobytych $\mathrm{w}$ okręgu. Tabela 2 natomiast ukazuje, ilu kandydatów zajmujących dane miejsce na liście zdobyło mandat. Porównując dane z obu tabel, możemy zatem sprawdzić, czy jeśli ugrupowanie zdobyło w okręgu co najmniej 2 mandaty, to przypadły one kandydatom z pierwszego i drugiego miejsca na liście, jeśli 3 mandaty - czy zdobyli je kandydaci z miejsc 1., 2. i 3. (zgodnie z działaniem efektu kolejności i pojęciem „miejsc mandatowych”). W obu tabelach punktem odcięcia jest liczba 12, ponieważ jest to największa liczba mandatów zdobyta przez ugrupowanie w jednym okręgu, a zatem także liczba określająca ostatnie „miejsce mandatowe” w tym okręgu i liście. W obliczeniach został pominięty jedynie mandat zdobyty przez Mniejszość Niemiecką.

Tabela 1. Liczba okręgów, w których ugrupowania uczestniczyły w podziale mandatów

\begin{tabular}{|c|c|c|c|c|c|c|c|}
\hline \multicolumn{2}{|c|}{ Komitet Wyborczy } & PiS & $\mathrm{PO}$ & Kukiz'15 & Nowoczesna & PSL & \multirow{3}{*}{$\begin{array}{l}\text { Liczba } \\
\text { przypadków } \\
\text { (dla wszystkich } \\
\text { komitetów) } \\
\text { zdobycia co } \\
\text { najmniej } \\
\text { x mandatów }\end{array}$} \\
\hline $\begin{array}{l}\text { Łączna licz } \\
\text { zdobytych }\end{array}$ & datów & 235 & 138 & 42 & 28 & 16 & \\
\hline \multicolumn{2}{|c|}{$\begin{array}{l}\text { Liczba okręgów, } \\
\text { w których Komitet } \\
\text { zdobył mandaty }\end{array}$} & 41 & 41 & 40 & 24 & 15 & \\
\hline \multirow{12}{*}{$\begin{array}{l}\text { Liczba } \\
\text { okręgów, } \\
\text { w których } \\
\text { Komitet } \\
\text { zdobył co } \\
\text { najmniej x } \\
\text { mandatów }\end{array}$} & $x=1$ & 41 & 41 & 40 & 24 & 15 & 161 \\
\hline & $x=2$ & 41 & 39 & 2 & 3 & 1 & 86 \\
\hline & $x=3$ & 41 & 28 & 0 & 1 & 0 & 70 \\
\hline & $x=4$ & 37 & 18 & 0 & 0 & 0 & 55 \\
\hline & $x=5$ & 30 & 9 & 0 & 0 & 0 & 39 \\
\hline & $x=6$ & 19 & 2 & 0 & 0 & 0 & 21 \\
\hline & $x=7$ & 11 & 1 & 0 & 0 & 0 & 12 \\
\hline & $x=8$ & 5 & 0 & 0 & 0 & 0 & 5 \\
\hline & $x=9$ & 1 & 0 & 0 & 0 & 0 & 1 \\
\hline & $x=10$ & 1 & 0 & 0 & 0 & 0 & 1 \\
\hline & $\mathrm{x}=11$ & 0 & 0 & 0 & 0 & 0 & 0 \\
\hline & $x=12$ & 1 & 0 & 0 & 0 & 0 & 1 \\
\hline
\end{tabular}

Źródło: Obliczenia własne na podstawie danych PKW. 
Tabela 2. Liczba kandydatów, którzy uzyskali mandat z wyszczególnieniem miejsca na liście, z którego startowali w wyborach

\begin{tabular}{|c|c|c|c|c|c|c|c|}
\hline Komitet & czy & PiS & $\mathrm{PO}$ & Kukiz'15 & Nowoczesna & PSL & Liczba \\
\hline $\begin{array}{l}\text { Łączna liczba } \\
\text { mandatów }\end{array}$ & tych & 235 & 138 & 42 & 28 & 16 & $\begin{array}{l}\text { którzy uzyskali } \\
\text { mandat }\end{array}$ \\
\hline $\begin{array}{l}\text { Liczba okręg } \\
\text { Komitet zdol }\end{array}$ & $\begin{array}{l}\text { xtórych } \\
\text { ndaty }\end{array}$ & 41 & 41 & 40 & 24 & 15 & $\begin{array}{l}\mathrm{z} \text { danego } \\
\text { miejsca na }\end{array}$ \\
\hline & 1. & 41 & 41 & 40 & 24 & 15 & 161 \\
\hline & 2. & 38 & 36 & 0 & 3 & 0 & 77 \\
\hline & 3. & 34 & 19 & 0 & 1 & 0 & 54 \\
\hline Liczba & 4. & 29 & 12 & 1 & 0 & 0 & 42 \\
\hline $\begin{array}{l}\text { Kandyaatow, } \\
\text { którzy }\end{array}$ & 5. & 22 & 3 & 0 & 0 & 0 & 25 \\
\hline uzyskali & 6. & 14 & 11 & 1 & 0 & 0 & 26 \\
\hline startując & 7. & 12 & 3 & 0 & 0 & 0 & 15 \\
\hline $\mathrm{z}$ danego & 8. & 11 & 3 & 0 & 0 & 0 & 14 \\
\hline liście & 9. & 5 & 1 & 0 & 0 & 0 & 6 \\
\hline & 10. & 11 & 2 & 0 & 0 & 0 & 13 \\
\hline & 11. & 4 & 0 & 0 & 0 & 0 & 4 \\
\hline & 12. & 4 & 1 & 0 & 0 & 0 & 5 \\
\hline
\end{tabular}

Źródło: Obliczenia własne na podstawie danych PKW.

Przedstawione zestawienia wyraźnie wskazują na związek między miejscem na liście wyborczej a sukcesem wyborczym kandydata. Najpewniejsza dla zdobycia mandatu jest pierwsza pozycja, jeśli bowiem komitet zdobył w okręgu przynajmniej jeden mandat, to w 100\% przypadków przypadł on kandydatowi z pierwszego miejsca na liście. Widoczny jest także wyraźny spadek liczby kandydatów zdobywających mandaty z dalszych miejsc na liście. Analizując wyniki wyborcze wyłącznie pod tym kątem, można śmiało orzec, że miejsce na liście ma kluczowe znaczenie dla sukcesu wyborczego kandydata.

Z danych zawartych w powyższych tabelach odczytać można jednak, że choć Prawo i Sprawiedliwość zdobyło co najmniej 2 mandaty we wszystkich okręgach wyborczych, to już nie wszyscy kandydaci zajmujący drugie miejsce na liście wyborczej tego komitetu uzyskali mandat. Podobnie było w wypadku Platformy Obywatelskiej: na 39 przypadków, kiedy partia ta uzyskała co najmniej 2 mandaty w okręgu - trzech kandydatów $\mathrm{z}$ drugich miejsc nie uczestniczyło w podziale mandatów w ramach listy. Komitetami niewpisującymi się w schemat efektu kolejności były także Kukiz'15 oraz Polskie Stron- 
nictwo Ludowe. W okręgach, w których pierwsze z ugrupowań zdobyło po dwa mandaty, drugi mandat przypadł kandydatom z czwartego i szóstego miejsca na liście wyborczej. PSL zdobyło natomiast dwa mandaty tylko w jednym okręgu wyborczym i drugi „Zwycięski” kandydat zajmował pozycję 32. (ostatnią na liście).

\section{Interwencyjny wpływ listy półotwartej}

Opisane odstępstwa od występowania efektu kolejności skłaniają do dokładniejszego przyjrzenia się wynikom wyborczym poszczególnych kandydatów. Warto w tym miejscu wrócić do kwestii głosowania preferencyjnego i sprawdzić, w jakim stopniu wyborcy wykorzystują tę możliwość. W tym celu przeprowadzono symulację podziału mandatów według zasad systemu proporcjonalnego, ale z listami zamkniętymi. Liczba mandatów, która rzeczywiście przypadła danej liście wyborczej w okręgu, pozostała niezmieniona, mandaty zostały jednak przydzielone kandydatom nie według największej liczby głosów (uzyskanego poparcia), lecz według uprzednio ustalonej przez komitet kolejności na liście. Innymi słowy, symulacja pozwoliła na pokazanie, ilu kandydatów zajmujących na liście wyborczej „miejsca niemandatowe” zdobyło mandat - a tym samym odebrało go kandydatom zajmującym „miejsca mandatowe”. Liczby mandatów uzyskanych przez poszczególne ugrupowania niezgodnie z kolejnością kandydatów na liście wyborczej przedstawia tabela 3. Ponownie pominięty został mandat zdobyty przez Mniejszość Niemiecką.

Tabela 3. Liczba mandatów uzyskanych przez kandydatów zajmujących „miejsca niemandatowe”

\begin{tabular}{l|c|c|c|c|c|c}
\hline \multicolumn{1}{c|}{ Komitet wyborczy } & PiS & PO & Kukiz'15 & .N & PSL & Ogółem \\
\hline $\begin{array}{l}\text { Liczba zdobytych } \\
\text { mandatów }\end{array}$ & 235 & 138 & 42 & 28 & 16 & 459 \\
\hline $\begin{array}{l}\text { Liczba mandatów } \\
\text { zdobytych z „miejsc } \\
\text { mandatowych” }\end{array}$ & 188 & 105 & 40 & 28 & 15 & 376 \\
\hline $\begin{array}{l}\text { Liczba mandatów } \\
\text { zdobytych z „miejsc } \\
\text { niemandatowych” }\end{array}$ & 47 & 33 & 2 & 0 & 1 & 83 \\
\hline $\begin{array}{l}\text { Liczba list, które } \\
\text { zdobyły co najmniej } 2 \\
\text { mandaty }\end{array}$ & 41 & 39 & 2 & 3 & 1 & 86 \\
\hline $\begin{array}{l}\text { Liczba list, } \\
\text { w których wystąpiły } \\
\text { „przetasowania” }\end{array}$ & 34 & 25 & 2 & 0 & 1 & 62 \\
\hline
\end{tabular}

Źródło: Obliczenia własne na podstawie danych PKW.

Wyniki przeprowadzonej symulacji wskazują, że prawie jedna piąta mandatów została uzyskana przez kandydatów, którzy przy zastosowaniu systemu list zamkniętych 
nie uczestniczyliby w podziale mandatów. Zamiast nich mandaty zdobyliby kandydaci umieszczeni na wyższych pozycjach na liście. Świadczy to bezsprzecznie o występowaniu stałego w czasie (bo zidentyfikowanego w ten sam sposób odnośnie do wyborów z lat 2001-2011 przez Gendźwiłła i Raciborskiego), interwencyjnego wpływu głosów preferencyjnych na sukces wyborczy kandydatów oraz przeczy tezie o uzależnieniu sukcesu wyborczego wyłącznie od miejsca zajmowanego na liście wyborczej. Jest to także dowód na występowanie rywalizacji pomiędzy kandydatami z tej samej listy, ponieważ to indywidualny wynik decyduje o kolejności rozdzielania mandatów. Jeżeli zatem kandydaci z tej samej listy muszą z sobą rywalizować, nie mogąc opierać się wyłącznie na identyfikacji partyjnej, warto zastanowić się nad tym, jakie czynniki decydują o ich sukcesie wyborczym.

\section{Efekt lokalności}

Ostatnia część artykułu przedstawia analizę wyników wyborów z dwóch okręgów wyborczych (nr 4 i 5 - z siedzibą Okręgowej Komisji Wyborczej odpowiednio w Bydgoszczy i Toruniu) stanowiących łącznie obszar województwa kujawsko-pomorskiego. Badaniu pod kątem występowania efektu lokalności zostały poddane wyniki dwóch największych ugrupowań politycznych, które w 2015 r. uczestniczyły w podziale mandatów: Prawa i Sprawiedliwości oraz Platformy Obywatelskiej. Ograniczenie liczby komitetów wynika $z$ faktu, iż jedynie te dwa ugrupowania zdobyły w danych okręgach więcej niż jeden mandat.

W zakres terytorialny okręgu numer $4 \mathrm{z}$ siedzibą Okręgowej Komisji Wyborczej w Bydgoszczy wchodzi 8 powiatów oraz miasto na prawach powiatu - Bydgoszcz. W okręgu tym do zdobycia jest 12 mandatów. W ostatnich wyborach liczba uprawnionych do głosowania wynosiła 804077 osób, a oddanych zostało 374277 ważnych głosów. Listy wyborcze obu analizowanych komitetów wyborczych liczyły po 24 kandydatów.

Okręg wyborczy nr 5 z siedzibą Okręgowej Komisji Wyborczej w Toruniu dzieli się na obszar trzech miast na prawach powiatu: Grudziądza, Torunia i Włocławka oraz 11 powiatów. W okręgu tym do podziału jest 13 mandatów. W ostatnich wyborach liczba uprawnionych do głosowania wynosiła 832502 osoby, a oddanych zostało 362510 ważnych głosów. Listy wyborcze obu analizowanych komitetów wyborczych liczyły po 26 kandydatów.

W pierwszej kolejności sprawdzeniu zostanie poddana hipoteza o interwencyjnym wpływie głosowania preferencyjnego. Na podstawie zestawienia miejsca kandydata na liście wyborczej z miejscem, które zajął on w rankingu utworzonym na podstawie liczby zdobytych głosów, można ocenić, że wielkość poparcia nie wynika wprost z pozycji zajmowanej na liście wyborczej. Kolejność kandydatów w rankingach obu ugrupowań nie odpowiada pierwotnej kolejności kandydatów na listach wyborczych. Ponadto na listach PiS w obu okręgach oraz na liście PO w okręgu nr 5 doszło do zdobycia mandatu przez kandydatów zajmujących „miejsca niemandatowe”. Lista PiS z okręgu nr 4 zdobyła pięć 
mandatów - uzyskali je kandydaci z miejsc 1., 2., 3., 7. i 4. (kolejność według liczby głosów); lista $\mathrm{PO}$ z tego okręgu zdobyła cztery mandaty, które uzyskali kandydaci z miejsc 1., 2., 4., i 3. W okręgu nr 5 lista PiS zdobyła sześć mandatów, a uzyskali je kandydaci z miejsc 5., 1., 4., 3., 17. i 2., natomiast lista PO zdobyła cztery mandaty, obsadzając kandydatów z miejsc 2., 1., 26. i 6 . Warto zauważyć, że kandydaci z „miejsc niemandatowych", uzyskując wynik pozwalający na zdobycie mandatu, wyprzedzili $\mathrm{w}$ rankingu nie tylko kandydata z ostatniego (lub ostatnich dwóch) „miejsc mandatowych”, ale także kandydatów umieszczonych na wyższych pozycjach. W sytuacji gdy mandaty zdobyli wyłącznie kandydaci z „miejsc mandatowych” (lista PO w okręgu nr 4), ranking ich wyników także różnił się od pierwotnej kolejności na liście.

Wobec potwierdzenia hipotezy o interwencyjnym wpływie zastosowania listy półotwartej kolejnym krokiem w badaniu było poddanie analizie jednej z cech kandydata, mogącej stanowić determinantę jego indywidualnego sukcesu wyborczego. Cechą tą była lokalność kandydata rozumiana jako pochodzenie kandydata $\mathrm{z}$ danego powiatu, identyfikowane na podstawie danych udostępnianych przez Państwową Komisję Wyborczą. Postawione zostały następujące pytania:

1) Jaki jest geograficzny rozkład poparcia kandydatów, tzn. czy składają się na nie głosy z całego okręgu wyborczego, czy swój wynik wyborczy kandydaci zawdzięczają rodzimym powiatom? Innymi słowy, czy kandydat uzyskuje najwięcej głosów z powiatu, $\mathrm{z}$ którego pochodzi?

2) Jak głosują wyborcy w powiatach — na kandydata rodzimego czy lidera listy?

3) Jakie poparcie w skali powiatu uzyskują dla listy kandydaci lokalni?

4) Czy większe szanse wyborcze mają kandydaci pochodzący z powiatów o większej liczbie mieszkańców (a tym samym większej liczbie osób uprawnionych do głosowania)?

Aby odpowiedzieć na te pytania, wyniki wyborcze kandydatów obu komitetów zostały przedstawione jako procent głosów oddanych na partię w danym powiecie. Kluczowymi zmiennymi były: pozycja na liście wyborczej, miejsce zameldowania, wynik wyborczy uzyskany przez kandydata w rodzimym powiecie, najlepszy wynik kandydata, liczba kandydatów o tej samej lokalności, startujących w danym okręgu z danej listy, oraz wielkość powiatu wyrażona liczbą osób uprawnionych do głosowania.

Dane wskazują, że prawie trzy czwarte $(72,92 \%)$ kandydatów uzyskało największe poparcie w swoim rodzimym powiecie ( $\mathrm{w}$ badaniu nie uwzględniono kandydatów zameldowanych poza okręgiem wyborczym, w którym startowali). Zaznaczyć należy, że kiedy kandydat był zameldowany $\mathrm{w}$ mieście na prawach powiatu lub powiecie ziemskim przylegającym do tego miasta (np. Bydgoszcz i powiat bydgoski, Toruń i powiat toruński), obie jednostki były traktowane jako powiat rodzimy. Przykładowo Domicela Kopaczewska z listy PO w okręgu nr 5 zameldowana we Włocławku najwięcej głosów uzyskała w powiecie włocławskim. Odwrotna sytuacja: Zbigniew Pawłowicz z listy PO w okręgu nr 4 zameldowany w powiecie bydgoskim najwięcej głosów uzyskał w Bydgoszczy.

Biorąc pod uwagę, ilu wyborców w danym powiecie głosuje na kandydata rodzimego, a ilu na lidera listy, można spostrzec, że w ponad połowie $(54,55 \%)$ powiatów największe poparcie uzyskał kandydat pochodzący z niego. Tutaj również musimy zwrócić 
uwagę na przypadki, gdy kandydat zameldowany w mieście na prawach powiatu wygrywa w powiecie ziemskim (lub na odwrót). Byli to między innymi: Marzenna Drab z Grudziądza (lista PiS w okręgu nr 5), która zdobyła jedną czwartą poparcia dla swojej partii w powiecie grudziądzkim, czy wspomniana już Domicela Kopaczewska (lista PO w okręgu nr 5) zameldowana we Włocławku, która w powiecie włocławskim pozyskała dla partii prawie jedną trzecią głosów. Po uwzględnieniu tych wypadków byłoby to już ponad $60 \%$ powiatów. Jeśliby natomiast stworzyć rankingi kandydatów według największej popularności w poszczególnych powiatach, to na 16 powiatów, w których nie wygrał kandydat rodzimy, w 4 znalazł się on na drugim miejscu za liderem listy, w 2 znalazł się na drugim miejscu za zwycięzcą w całym okręgu, a w 4 - zajął czwarte miejsce, za kandydatami, którzy uzyskali największe poparcie w całym okręgu. Widać więc, że większość wyborców wysoko ceni pochodzących z ich powiatu kandydatów.

Warta uwagi jest również kwestia tego, jaki procent poparcia $\mathrm{w}$ danym powiecie przynosi partii kandydat lub kandydaci lokalni. Okazuje się, że jeśli z listy komitetu w powiecie startował kandydat lub kandydaci lokalni, to w $65 \%$ wypadków zdobyli oni więcej głosów niż lider listy (z obliczeń wyłączono powiaty, w których kandydatem rodzimym był lider listy). Średnio kandydaci pochodzący z powiatu zdobywali dla partii ponad 30\% poparcia $\mathrm{w}$ tym powiecie, a dla porównania liderzy list zdobyli w okręgu $\mathrm{nr} 5$ średnio ok. $13 \%$ poparcia, a w okręgu nr $4-$ ok. $25 \%$.

Ostatnim aspektem analizy było pytanie, czy status kandydata lokalnego może wpłynąć na sukces wyborczy oraz czy i na ile jest to zależne od wielkości powiatu, z którego pochodzi kandydat. Najciekawszym przypadkiem w analizowanej próbie jest Joanna Borowiak startująca w okręgu nr 5 z listy PiS z numerem 17. Zdobyła ona mandat poselski, wyprzedzając w poparciu w skali całego okręgu Marzennę Drab startującą z pozycji nr 6 („miejsce mandatowe”), która ostatecznie mandatu nie zdobyła. Warto więc zastanowić się, co mogło wpłynąć na sukces wyborczy Joanny Borowiak. W tym celu porównane zostały wyniki wyborcze obu kandydatek w ich rodzimych powiatach (miastach na prawach powiatu Włocławku i Grudziądzu) oraz powiatach ziemskich włocławskim i grudziądzkim, w których uzyskały one największe poparcie.

W pierwszej kolejności podnieść należy, że Joanna Borowiak uzyskała we Włocławku aż 53,58\% poparcia dla partii, natomiast Marzenna Drab w Grudziądzu jedynie 36,92\%. W powiatach ziemskich zaś panie uzyskały odpowiednio 7,85\% i $25,41 \%$ poparcia zdobytego przez komitet. Kiedy połączymy wyniki z miast na prawach powiatu z danymi z powiatów ziemskich, okazuje się, że obie kandydatki uzyskały ok. 33\% głosów zdobytych w tych powiatach przez całą partię. Znaczenia nabiera zatem wielkość tych części okręgu wyborczego oraz wielkość poparcia komitetu. To ostatnie można określić jako porównywalne (PiS uzyskało odpowiednio 30\% i 34\% poparcia), jednak jeśli chodzi o liczbę osób uprawnionych do głosowania, różnica sięga ponad 55 tysięcy osób. Ostateczna liczba głosów oddanych na komitet jest większa we Włocławku i powiecie włocławskim o ponad 9 tysięcy. Oznacza to, że przy podobnym procentowo poparciu dla komitetu i niemalże równym procentowo poparciu dla kandydatek ta, która jest kandydatką lokalną z mniejszego powiatu, automatycznie ma mniejsze szanse na sukces wy- 
borczy i musi szukać poparcia także w innych powiatach lub też konkurować z innymi lokalnymi kandydatami.

Taka strategia przyniosła zwycięstwo Joannie Borowiak, ponieważ zdobywając we Włocławku ponad 50\% głosów partii, samymi głosami z tego miasta i poparciem uzyskanym z powiatu włocławskiego wyprzedziła $\mathrm{w}$ okręgowym wyścigu po mandat Marzennę Drab. Ta ostatnia natomiast $w$ dwóch bliskich sobie powiatach straciła mniej głosów na rzecz pozostałych kandydatów lokalnych, i - co ciekawe - pozyskała także ponad $10 \%$ poparcia $\mathrm{w}$ powiecie chełmińskim (ale również stosunkowo niewielkim). Było to jednak za mało głosów, aby pokonać kandydatkę z Włocławka.

\section{Podsumowanie}

$\mathrm{W}$ artykule został podniesiony problem wpływu głosowania preferencyjnego na sukces wyborczy rozumiany jako wielkość poparcia oraz zdobycie mandatu posła w warunkach systemu proporcjonalnego $\mathrm{z}$ listami półotwartymi. Z uwagi na fakt, że $\mathrm{w}$ tym systemie podmiotem transformacji głosów na mandaty są ugrupowania polityczne, a w następnej kolejności zdobyte mandaty przydzielane są kandydatom według wielkości ich poparcia, a nie według kolejności, w jakiej zostali umieszczeni na liście wyborczej, kandydaci znajdują się w sytuacji, w której chcąc zdobyć mandat poselski, muszą rywalizować o głosy wyborców z osobami z tej samej listy. Konieczne jest zatem oparcie kampanii wyborczej na czymś innym niż wyłącznie identyfikacji partyjnej. Pojawia się więc pytanie o to, jakie fakty czy cechy będą podstawą do skutecznego wyróżnienia się spośród innych kandydatów. W artykule za taką zmienną przyjęto lokalność kandydata, rozumianą jako wspólne miejsce zamieszkania kandydata i wyborcy (na poziomie powiatu), ustalane na podstawie danych PKW.

W pierwszej kolejności analiza wyników wyborczych z wyborów do Sejmu w 2015 r. wykazała, że w tejże elekcji dzięki systemowi list półotwartych mandaty zdobyły osoby zajmujące na listach wyborczych nie tylko „miejsca mandatowe”. Oznacza to, że miejsce na liście wyborczej nie jest jedynym czynnikiem mającym wpływ na sukces wyborczy, ponieważ prawie jedna piąta mandatów została uzyskana przez kandydatów, którzy przy zastosowaniu systemu list zamkniętych nie uczestniczyliby w podziale.

Pogłębiona analiza cząstkowych wyników wyborczych (z dwóch okręgów wyborczych) miała na celu ocenę występowania efektu lokalności, tzn. oddziaływania miejsca zamieszkania kandydata na jego indywidualny sukces wyborczy. Badanie wykazało, że prawie trzy czwarte kandydatów uzyskało największe poparcie w skali okręgu w swoim rodzimym powiecie. Co więcej, w ponad połowie powiatów największe poparcie uzyskał kandydat pochodzący z tego powiatu, a nie lider listy. Dane te pozwalają wysunąć tezę o znaczeniu lokalności kandydata dla wyborcy. Najciekawszym problemem jest kwestia, czy większe szanse wyborcze mają kandydaci pochodzący z powiatów o większej liczbie mieszkańców - w artykule przeanalizowana na podstawie wyników wyborczych dwóch kandydatek z listy PiS w okręgu nr 5. W tym wypadku rzeczywiście wielkość miasta na 
prawach powiatu przy podobnym procentowo poparciu dla komitetu i niemalże równym procentowo poparciu dla kandydatek miała znaczny wpływ na zdobycie mandatu przez jedną z nich.

Należy oczywiście podkreślić, że są to badania prowadzone na niewielkiej próbie i z całą pewnością wymagają dalszej, poszerzonej analizy.

\section{Bibliografia}

Aronson E., Wilson T.D., Akert R.M., Psychologia społeczna, przeł. Joanna Gilewicz, Zysk i S-ka, Poznań 2006.

Blom-Hansen J. et al., Ballot position and election results: Evidence from a natural experiment, „Electoral Studies" 2016, nr 44.

Carey J.M., Shugart M.S., Incentives to cultivate a personal vote: A rank ordering of electoral formulas, „Electoral Studies" 1995, nr 4.

Flis J., Głos preferencyjny - złudzenie wyboru, [w:] Oblicza polskiego systemu politycznego, red. B. Krauz-Mozer, K. Sobolewska-Myślik, Wydawnictwo Adam Marszałek, Toruń 2007.

Flis J., Zludzenia wyboru. Społeczne wyobrażenia i instytucjonalne ramy w wyborach Sejmu i Senatu, Wydawnictwo Uniwersytetu Jagiellońskiego, Kraków 2014.

Gallagher M., Social backgrounds and local organization of members of the Irish Dail, „Legislative Studies Quarterly" 1985, nr (10) 3.

Gendźwiłł A., Raciborski J., Jak głosuja wyborcy w warunkach preferencyjnych list wyborczych: przypadek Polski, „Decyzje” 2014, nr 22.

Jankowski M., Voting for locals: Voters's information processing strategies in open-list PR systems, „Electoral Studies" 2016, nr 43.

Jarentowski M., Struktura głosu: niepożądane skutki personalizacji, [w:] Niedemokratyczne wymiary demokratycznych wyborów, red. J. Szymanek, Wyd. Sejmowe, Warszawa 2016.

Korzeniowski K., Psychospołeczne uwarunkowania zachowań wyborczych, [w:] Podstawy psychologii politycznej, red. K. Skarżyńska, Wydawnictwo Zysk i S-ka, Poznań 2002.

Marcinkiewicz K., Electoral contexts that assist voter coordination: Ballot position effects in Poland, „Electoral Studies" 2014, nr 33.

Matyja R., Od ruchu „trzech tenorów” do partii Tuska, [w:] Platforma Obywatelska, red. M. Migalski, Toruń 2009.

Put G., Maddens B., The effect of local ties on the electoral success of Belgian/Flemish party candidates: a multilevel analysis, Belgian-Dutch Political Science Conference, Ghent, Belgia, 30-31.05.2013.

Raciborski J., Rywalizacja czy kooperacja? O listach partyjnych w wyborach parlamentarnych, [w:] Demokracja w Polsce. Doświadczenie zmian, red. U. Jakubowska, K. Skarżyńska, Academica - Wydawnictwo SWPS, Warszawa 2005.

Shugart M.S., Valdini M.E., Suominen K., Looking for locals: Voter information demands and personal voteearning attributes of legislators under proportional representation, „American Journal of Political Science" 2005, $\mathrm{nr} 49$.

Sokala A., Michalak B., Uziębło P., Leksykon prawa wyborczego i referendalnego oraz systemów wyborczych, Wolters Kluwer Polska SA, Warszawa 2013.

Tavits M., Effect of local ties on electoral success and parliamentary behavior: The case of Estonia, „Party Politics" 16, 2010, nr 2. 


\section{Competition between candidates from the same party against each other as a consequence of the open-list PR system in elections to the Polish Sejm (lower house)}

Keywords: open-list PR system, personal votes, ballot position effect, locality, local ties, personal vote-earning attributes

Summary

Although a open-list PR system guarantees the voter the possibility of nominating a specific candidate from the list, which, according to voters, should represent his political option, it is often said that voters do not exercise that power, and that for the election results the most important is candidate's ballot position. However, we know that the personal votes have a real impact on the electoral success. The question is what prompts voters to vote for a particular candidate. The purpose of this article is to analyze the results of the elections to the Polish Sejm from 2015 in terms of the ballot position effect, the intervention effect of the personal votes on the electoral success and effect of one of the determinants of the individual candidate's success - locality/local ties of candidate. 